\title{
Examining the Relationship between Teacher Leadership Culture and Teacher Professionalism: Quantitative Study
}

\author{
Hanifi Parlar ${ }^{1}$, Ramazan Cansoy ${ }^{2}$, Ali Çağatay Kılınç² \\ ${ }^{1}$ Istanbul Commerce University, Faculty of Humanities and Social Sciences Department of Educational Sciences, \\ Istanbul, Turkey \\ ${ }^{2}$ Karabük University, Faculty of Letters, Department of Educational Sciences, Karabuk, Turkey \\ Correspondence: Hanifi Parlar, Istanbul Commerce University, Faculty of Humanities and Social Sciences Department of \\ Educational Sciences, Imrahor Cad. No: 90 Sütlüce-Beyoglu-Istanbul, Turkey.
}

Received: June 20, 2017

doi:10.11114/jets.v5i8.2499
Accepted: June 30, 2017 Online Published: July 2, 2017

URL: https://doi.org/10.11114/jets.v5i8.2499

\begin{abstract}
The aim of this study was to examine the relationships between schools' levels of having teacher leadership culture and teachers' professional behaviors. A total of 254 teachers working in primary and secondary schools located in Üsküdar district of Istanbul province participated in the study. The "Teacher Leadership Culture Scale" and the "Teacher Professionalism Scale" were used to collect the research data. The arithmetic mean, Pearson Product-Moment Correlation Coefficient and Multiple Linear Regression analysis were used in the analysis of the data. In the study, schools' levels of having teacher leadership culture and the professionalism characteristics of teachers were found to be above the medium level. Furthermore, significant positive relationships were found between professional cooperation, school administrator's support and the level of having a supportive working environment of the schools' levels of having teacher leadership culture and teacher professionalism. The results of the study revealed that the dimensions of supportive working environment and professional cooperation from among teacher leadership culture characteristics were significant predictors of teacher professionalism. The results of the study were discussed in relation to the relevant literature, and some suggestions were made.
\end{abstract}

Keywords: teacher professionalism, teacher leadership culture, teacher leadership, school

\section{Introduction}

The teacher is one of the most basic variables of quality education (Hoque, Alam and Abdullah, 2011; McDonald, Son, Hindman and Morrison, 2005; Newmann, King and Youngs, 2000; Poekert, 2012; Şişman, 2011). The qualified teacher has a critical importance in decreasing the differences in success among students who are socio-economically disadvantaged (OECD [Organisation for Economic Co-operation and Development], 2016) and in transforming schools into effective learning environments (Hildebrandt and Eom, 2011; Rolff, 2008). In this context, it can be considered that professional teacher behaviors can make a significant contribution to the increase in the quality of education by taking them into the center of training, which is the technical essence of the school. When professional behaviors are addressed within the context of the teaching profession, it is understood that the concept refers to the fact that teachers do the best of their profession and take responsibility for ensuring student learning (Tschannen-Moran, Parish and DiPaola, 2006). When the above statements are considered as a whole, it can be stated that teacher professional behaviors are an important variable in the improvement of the quality of education and student learning. In this regard, it is considered important to examine the relationship of the concept with different organizational and personal variables to ensure that teacher professional behaviors are strengthened.

In the literature, it is observed that the relationships of professional behaviors of teachers with different personal or organizational variables have become the research subject. In this context, there are studies showing that the effectiveness of bureaucratic structures of schools (Cerit, 2012), the support culture in schools (K1linç, 2014; Tschannen-Moran, 2009), trust in administrator (Koşar, 2015), healthy school climate (Hoy and Sweetland, 2001) and professional solidarity and cooperation (Yirci, 2017) are effective in teachers' professional behaviors. In this context, it is thought that one of the variables related to teacher professional behaviors is a school culture that supports teacher leadership. It is observed that supportive working environment, professional cooperation and administrator's support are 
at a strong level in such a school culture (Demir, 2014). The cooperation between teachers, professional sharings and supportive school conditions strengthen the professional behaviors of teachers at schools (Kılınç, 2014; Tschannen-Moran, 2009; Dean, 2011; Webb et al., 2004). In this respect, a school culture that supports teacher leadership is expected to be related to the professional behaviors of teachers. Therefore, it is considered important to reveal which features of school culture that supports teacher leadership are associated with teachers' professional behaviors in terms of practical inferences. On the other hand, while teachers' professional behaviors are discussed with different studies in the literature (eg., Hildebrandt and Eom, 2011; OECD, 2016; Tschannen-Moran, 2009), it can be said that the discussions on the subject in the national literature are still new (Bayhan, 2011; Cansoy and Parlar, 2017; Demirkasımoğlu, 2010; Karaca, 2015; Koşar, 2015; Kılınç, 2014; Yirci, 2017) and that there is a need for studies that examine different aspects of teachers' professional behaviors. In this respect, it is considered that the present study will contribute to the national literature with the findings produced on the subject and to the practitioners at the point of increasing teachers' professional behaviors.

\subsection{Culture, Organization, and School Culture}

Culture, in the most general sense, emphasizes the forms of understanding that reveal the way the activities in the organization are conducted and the common beliefs of individuals forming the group (Robbins, 1990), and these beliefs also reflect the perception forms around the core values (Schein, 2010). Organizations are the places where beliefs, values and the forms of perception take shape or are shaped. In this context, organizational culture is formed around common beliefs or values and also enables the formation of an identity specific to the organization and the differentiation of the organization from other organizations (Hoy, Tarter and Bliss, 1990). In other words, beliefs, values and some common acceptances should be considered as a whole in the formation of some common perceptions in the organization, in this respect, it can be argued that organizational culture is formed by the combination of communication, interaction and behavioral patterns.

Some classifications have been made for organizational culture. According to Harrison (1972), organizations are classified as power, role, task and individual culture. The culture in organizations in which the structure is established on formal power represents the structures with power culture, the culture in which written rules are dominant represents the structures with role culture, and the culture in which the objectives of the organization are considered significant represents the structures with task culture. The cultures in which the interests and objectives of employees are considered important and the organization is regarded as a tool to reach individual objectives constitute the individual culture. On the other hand, it is also observed that strong and weak culture classification is used for organizational culture. The cultures in which the efforts of the members of the organization are supported, originality is brought into the forefront, mutual respect and trust are high and common values are adopted constitute strong organizational cultures (Şişman, 2012). So, it can be argued that organizational culture is evaluated within the framework of some classifications and that the organization is addressed in an integrated way within the framework of the values, beliefs, and norms it has.

School culture is closely associated with what teachers feel, the way they do their work, their commitment to school and their work and their desires and expectations from the school (Demirtaş, 2010). The fact that the academic aspect at schools is brought to the forefront, studies aimed at making the courses more qualified, how teachers are motivated for school objectives, participation in processes at school, behaviors of school administrators, relationships between colleagues and student behaviors are among the important factors that determine the cultural characteristics of schools (Celep, 2002). The foundation of creating a strong and effective culture at school is based on compromising on common objectives and a certain vision and carrying out studies in a peaceful working environment and in harmony (Marzano, Waters and McNulty, 2005). As it can be understood from these statements, it can be said that school culture proceeds within the framework of the values, beliefs, and norms shared by teachers. The continuity and strengthening of this culture can be ensured by cooperation, understanding and mutual support at school.

\subsection{Teacher Leadership Culture}

Teacher leadership is addressed on the basis of effective teacher behaviors within the context of making education more qualified. The increase in the responsibilities of schools and the high expectations for educational quality have led to the increase in interest in teacher leadership (Smylie and Denie, 1990), and teacher leaders have been considered as supervisors, experts and organizational developers (Silva, Gimbert, Nolan, 2000). Teacher leadership emphasizes the qualifications of teachers for student learning and the behaviors to improve the quality of students (Danielson, 2006; Harris and Muijs, 2005). In addition to this, teacher leadership brings creating difference at schools (Crowther, Kaagen, Ferguson and Hann, 2009), suggesting and realizing a vision (Can, 2006), playing an active role in administrative processes (Smylie and Brownlee-Conyers, 1992) and adopting the changes at schools (Harris and Muijs, 2005) into the forefront. Playing an effective role in decision-making processes, implementing decisions for the school, making 
professional development widespread and being a model to the school community through professional development are important teacher leadership characteristics in structuring schools as a learning community (Beycioğlu, 2009). So, it can be argued that teacher leadership behaviors are all types of teacher attempts aimed at ensuring the development and effectiveness of the school.

Teacher leadership culture refers to a school atmosphere that supports teachers' leadership behaviors. The supportive working environment, professional cooperation and administrator's support are at a strong level in such a school atmosphere (Demir, 2014). Opportunities are offered for professional learning and leadership roles in a culture in which teacher leadership behaviors are supported. Furthermore, the teachers' unique behaviors are valued, and teachers are ensured to participate in decision-making processes at schools (Katzenmeyer and Moller, 2001). Furthermore, problems are regarded as an opportunity and learning tool, and teachers are seen as experts in a culture in which teacher leadership is supported (Danielson, 2006). As it can be understood from these statements, it can be said that cooperation is at a high level in the teacher leadership culture and that teachers have a say in their profession.

In this study, the teacher leadership culture is discussed as the schools where there are professional cooperation, administrator's support and supportive working environment (Demir, 2014). The characteristics of schools with teacher leadership culture are as follows, respectively: (i) professional cooperation emphasizes the development and improvement of the school (Borchers, 2009), structuring schools as a learning community (Chamberland, 2009; Danielson, 2006; Gaffney and Faragher, 2010; Harris and Muijs, 2005; Hunzicker, 2012) and carrying out collaborative studies in line with the common objectives (Chamberland, 2009; Gaffney and Faragher, 2010; McCay, Flora, Hamilton and Riley, 2001; Muijs and Harris, 2006;) (ii) school administrator's support emphasizes the distribution of leadership across the school (Brosky, 2009; Chamberland, 2009;), sharing in school management and processes (Beachum and Dentith, 2004), an encouraging understanding (Heller and Firestone, 1995) and effective feedback behaviors for the teacher (Buckner and McDowelle, 2000). Ensuring school administrator's support is associated with the fact that teachers exhibit more leadership behaviors at school and make use of professional development opportunities. (Demir, 2014). (iii) Supporting working environment emphasizes offering opportunities for teachers to increase educational quality (Chew and Andrews, 2010; York-Barr and Duke, 2004), creating an open environment to try new applications (Barth, 2000), developing an understanding based on trust and respect at schools (Beachum and Dentith, 2004; Gordin, 2010; York-Barr and Duke, 2004), opportunities for the curriculum development and the environment in which ideas are received in the management processes (Chew and Andrews, 2010). It also emphasizes the environments in which mutual trust and goodwill are dominating, and communication channels are open (Demir, 2014). So, it can be said that teachers share professional information and lead each other in a school culture in which teacher leadership is supported. Furthermore, it can be argued that participation is considered important and there is an intensive school atmosphere open to changes and innovations in these cultures.

\subsection{Teacher Professionalism}

The concept of professionalism is discussed and addressed within the context of different professions. It is stated that professionalism is shaped on the basis of knowledge and skill (Goepel, 2012). Professionalism has a wide range of application areas related to community service, expertise, professional standards, and selection, supervision and autonomy in going into the profession (Bureau and Suquet, 2009; Carr, 2000). In the literature, whether teaching profession is a professional occupation is discussed within the framework of semi-professionalism, whether the profession is under organizational control, and the limitation of autonomy (Demirkasımoğlu, 2010). Furthermore, professional behaviors are also discussed on the basis of occupational professionalization and professionalism (Raymond, 2006).

Professionalism is evaluated within the context of increasing the quality related to the application (Hargreaves, 2000), innovative approaches (Hess and Fennel, 2015; Kincheloe, 2004), competence to produce knowledge in the profession (Coleman, Gallagher and Job, 2012), capacity to reach high standards and being a role model in the field (Agezo, 2009). Furthermore, professionalism requires that individuals should be able to apply the best and recent developments in their fields to their profession and to take responsibility in this direction (Shantz and Prieur, 1996) and to focus on successful business practices (Demirkasımoğlu, 2010). On the other hand, teacher professional behaviors emerge as a whole when individual qualities come together with the experiences of the individual and refer to all kinds of attempts aimed at improving teaching (Gil'meeva, 1999). Teacher professional behaviors emphasize teachers' commitment to their profession, professional cooperation and high objectives for teaching. Along with these, they also refer to behaviors aimed at bringing student learning and education to more qualified levels and all kinds of attempts (Tschannen-Moran, Parish and DiPaola, 2006). It can be stated that teacher professionalism focuses on improving the quality of education, and in particular, on bringing the quality of student learning, which is the technical essence of the school, into the forefront (Hargreaves, 2000). So, it can be said that professional behaviors are associated with attempts aimed at increasing professional development, sharing, knowledge, and skills. 
Teacher professionalism can be divided into four different historical processes as pre-professional period, autonomous period, collective working period and post-professional period. In the pre-professional period, the teaching profession was considered as a technical and simple profession. In the autonomous period during which the autonomy of teachers was intensively discussed, the emphasis was placed on the ways of making professional decisions, having a say in practices for teaching, and original teacher roles. In the collective working period, it is observed that the emphasis was placed on professional collaborative learning culture and cooperation. Finally, in the post-professional period, school and teaching profession were questioned, and the teaching profession was redefined (Hargreaves, 2000).

It is observed that discussions about what the characteristics of professionalism are have been addressed in the dimensions such as autonomy, professional development, professional cooperation, behavior, and attitude. For example, in the report prepared by the OECD (2016), teacher professionalism is discussed with the dimensions of autonomy, peer cooperation, and professional knowledge. These dimensions and their features are expressed as follows: (i) autonomy refers to participation in decision-making, planning, and coordination processes, having more say in different areas of the school, and originality in teaching practices and evaluations (ii) peer cooperation refers to the fact that teachers improve each other by making observations, directing and leading other teachers, and all kinds of professional development activities (iii) professional knowledge refers to going through training aimed at gaining competence for teaching profession and processes such as selection and assessment, and having an understanding of lifelong learning. In another study, the characteristics of teacher professionalism were addressed in different dimensions. According to Evans (2011), teacher professionalism includes behavioral dimension, attitude dimension, and intellectual dimension. These dimensions and their features are as follows: (i) behavioral dimension is the competencies that teachers need to gain and the applications for student learning. (ii) attitude dimension brings teachers' attitudes and beliefs related to profession into the forefront and (iii) intellectual dimension brings the accumulation of knowledge, effective use of teaching methods and producing original ideas into the forefront. According to these statements, it can be said that it is important for the teacher to attach importance to the continuous development activities and acquire the necessary qualifications in the behavioral, attitudinal and intellectual dimensions for the profession.

\subsection{The Relationship between Teacher Leadership Culture and Teacher Professionalism}

Teacher leadership culture refers to a culture in which administrator's support, supportive working environment, and professional cooperation are felt (Demir, 2014). Professionalism behaviors emphasize teacher behaviors aimed at making student learning and educational quality more qualified (Tschannen-Moran, Parish and DiPaola, 2006). The development of teacher professionalism is associated with teachers' attempts to bring student learning to a higher level at school. In this respect, it may be considered important to provide teachers with a peaceful working environment in which they can act autonomously and can learn from each other as supportive and teachers. There are some pieces of evidence regarding the fact that teachers' professional behaviors can develop in a school culture that supports teacher leadership. A supportive environment that develops with the reliance on administrator (Koşar, 2017; Tschannen-Moran, 2009), a school structure that makes teachers' work easier (Cerit, 2012) and the support culture at school create a school atmosphere that supports professional behavior (K1lınç, 2014). While communication and cooperation are increasing in a mutual trust environment (Dean, 2011; Tschannen-Moran, 2009), teachers support each other, quickly adapt to innovation and try to improve the quality of student learning (Webb et al., 2004). A school culture in which professional development is considered important and which is supportive leads to positive changes in in-class practices of teachers (Hopkins, 2007). As it can be understood from these statements, teachers are expected to show the high levels of professional behaviors when they are provided with opportunities to try different teaching methods and opportunities for collaborative learning and working.

Along with a culture in which teacher leadership is supported, some changes can be expected in the behaviors of teachers to improve the quality of education because in schools where professional behaviors are widespread, problems and mistakes are seen as learning tools, and there is a collaborative environment among employees in different fields (Hoy and Sweetland, 2001). Teachers get the opportunity to learn and try with positive relationships among colleagues and share effective teaching practices (Geist, 2002). In this context, cooperation and solidarity among teachers may increase with a peaceful environment, and teachers can use what they learn to increase the quality of education in classrooms. On the other hand, it is stated that a rule-based, hierarchical and challenging school structure is a significant obstacle to professional behaviors (Yirci, 2017). Excessive workload and obstructive working environment (Adams and Gamage, 2008) and the fact that leadership belongs to a single person (Chew and Andrews, 2010) are significant obstacles for teachers to work in a more qualified manner. Therefore, it can be said that the fact that teachers exhibit professional behaviors is associated with a school culture that promotes teacher leadership because cooperation cultures provide collaborative learning, administrator's support encourages teachers to use more original methods, and a supportive working environment can encourage teachers to take more responsibility for student learning. In this context, 
the relationships between schools' levels of having teacher leadership culture and teacher professionalism characteristics were examined in the present study. In the study, answers to the following questions were sought:

1. According to teacher perceptions, what are the levels of teacher leadership culture and teacher professionalism at schools?

2. Are there significant relationships between professional cooperation, administrator's support and supportive working environment of teacher leadership culture characteristics and teacher professionalism?

3. Are professional cooperation, administrator's support, and supportive working environment dimensions of teacher leadership culture the significant predictors of teacher professionalism?

\section{Method}

\subsection{Research Design}

This study was designed in a relational model to examine the relationship between schools' levels of having teacher leadership culture and teacher professionalism. The dependent variable of the study is teacher professionalism, and the independent variable of the study is the professional cooperation, administrator's support and supportive working environment dimensions of teacher leadership culture.

\subsection{Population and Sample}

Primary and secondary school teachers working in Üsküdar district of Istanbul province in the 2016-2017 academic year constituted the participants of the study. 254 teachers who could be reached and were from suitable schools participated in the study. 187 (74\%) of the participants were female, and $67(26 \%)$ of them were male. $51(20 \%)$ teachers from primary school and $203(80 \%)$ teachers from secondary school participated in the study. The average age of the participants was 36.8 years. The teacher's average period of office at their schools was 4.83 years.

\section{Data Gathering Tools}

\subsection{Teacher Leadership Culture Scale}

This scale developed by Demir (2014) presents the characteristics of a school culture that supports teacher leadership. The scale consists of three dimensions called administrator's support, supportive working environment and professional cooperation and a total of 27 items. 5-point rating expressed between "(1) Strongly Disagree" and "(5) Strongly Agree" was used in the scale. The dimension of professional cooperation emphasizes studies for the realization of teachers' cooperation and common objectives. The exemplary items are "At this school, teachers talk about teaching strategies among themselves", "At this school, teachers are influenced by each other's works". Administrator's support emphasizes all kinds of administrator's supports for the realization of teachers' leadership behaviors. The exemplary items are "At this school, administrators work together with teachers" and "At this school, administrators respect teachers". Supportive working environment refers to behaviors that promote teacher leadership along with a mutual trust and good communication culture. The exemplary item is "We celebrate our successes at this school". The perception of school culture that promotes teacher leadership increases as the score obtained from the scale and the sub-dimensions increases. In his study, Demir (2014) stated that the structural coefficients of the items on the scale varied between .74 and .89 and that the dimension of professional cooperation explained $72 \%$ of the variance at the school supporting teacher leadership, the dimension of administrator's support explained $84 \%$ of it, and the dimension of supportive working environment explained $89 \%$ of it. The Cronbach's Alpha coefficients calculated for the scale were found to be .88 for professional cooperation, .91 for administrator's support and .88 for the supportive working environment.

When the relevant literature was examined, it was observed that this scale had so far been used as a data collection tool in one study (Demir, 2015). Therefore, it is necessary to determine whether the existing structure of the scale was verified in applications carried out in different samples. From this point of view, in the present study, the Confirmatory Factor Analysis (CFA) was performed to determine whether the existing 3-dimensional structure of the "Teacher Leadership Culture" scale was verified. According to the compliance indices calculated as a result of the CFA of the structure with 27 items and 3 dimensions, it was observed that the first-level model did not comply at the acceptable level. After a total of 5 modifications, it was observed that the 1 st level 3 dimensional structure was at acceptable values. $(\chi 2=795.06 ; \mathrm{p}<.05 ; \mathrm{df}=316 ; \chi 2 / \mathrm{df}=2,51 ; \mathrm{RMSEA}=.077 ; \mathrm{CFI}=.93 ; \mathrm{GFI}=.80, \mathrm{AGFI}=.76)$. Although the other compliance indices were at acceptable levels, it was thought that the low level of the GFI depended on the number of samples (Bayram, 2013). The standard factor loads of the items constituting the scale were found to be between .68 and .87. The Cronbach's Alpha coefficient calculated for the reliability of the whole scale for the present study was found to be .98 . The Cronbach's Alpha coefficients calculated for the reliability of sub-dimensions were found to be .93 for professional cooperation, .96 for administrator's support and .95 for the supportive working environment. 


\subsection{Teacher Professionalism Scale}

The scale was developed by Tschannen-Moran, Parish, and DiPaola (2006) and adapted into Turkish by Cerit (2013). The scale has a one-dimensional structure and consists of 8 items. It was prepared with a rating of 5-point Likert-type between "(1) Never agree" and "(5) Completely agree". On the scale, there are items that reveal teachers' levels of exhibiting professional behaviors (Tschannen-Moran, Parish and DiPaola, 2006). It was stated that the factor load values of the scale items varied between .55 and .90 and that the total variance it explained was $61.62 \%$. The Cronbach's Alpha coefficient calculated for the whole scale was .90 (Cerit, 2013). The exemplary items from the scale are "Teachers provide strong social support to their colleagues" and "Teachers are dedicated to helping students". This scale was used in different studies.

This scale, which was adapted into Turkish by Cerit (2014), was used as a data collection tool by reproducing the findings on its validity and reliability in different studies (Kılınç, 2014; Koşar, 2015). Since it was observed that the scale had been applied on different samples, only the reliability of the scale was examined in the present study. In this context, the Cronbach's Alpha coefficient calculated for the scale was found to be .92 .

\section{Data Analysis}

The analysis of the data was basically carried out in two steps. In the first step, the data were examined in terms of missing or incorrect value, outliers, and multivariation. Average values were assigned to missing values. Sub-problems were analyzed in the second step. In the analysis of the sub-problems, the average value was calculated for each factor, and the analyses were performed over these factor values. Furthermore, multicollinearity between variables, variance inflation (VIF) and tolerance values were examined. The skewness and Q-Q chart, mode and median values were firstly examined for the normality of the data. In this context, the normality hypothesis was firstly tested to test the suitability of the data for the analysis to be performed. The skewness values of the variables within the context of the study were found to be in the range of (-.78) and (-1.3). It can be assumed that the distribution is normal depending on the fact that the skewness and kurtosis are between (+2) and (-2) (Gravetter and Wallnau, 2014; Trochim and Donnelly, 2006). Furthermore, the histogram and normal Q-Q charts were examined together for normality. It was observed that the mean, mode, and median values took values that were close to each other. When these results are examined together, it can be stated that the premise related to normality is realized. In the study, autocorrelation, multicollinearity and homoscedasticity features of the assumptions of the regression analysis were examined. The smallest of the tolerance values was found to be .16, and the highest of the VIF (Variance Inflation Factor) values was found to be 5.95. It was observed that the highest value of the CI (Condition Index) was 29.77. The facts that the tolerance value was less than .20 , the VIF value was greater than 10 , the CI value was greater than 30 , and the correlations between independent variables were .80 and over could be a sign of multicollinearity (Büyüköztürk, 2010). Furthermore, the Durbin-Watson (D.W) value was found to be (1.87) between the range of 1.5 and 2.5. The highest correlation $(r=.86)$ was found among the independent variables. Based on these results, it can be stated that no evidence was found for multicollinearity.

The arithmetic averages of the scores obtained in the analysis of the data were calculated to solve sub-problems in the study. Analyses were performed based on these values. The Pearson Product-Moment Correlation coefficient (r) was calculated to determine the relationships between the variables. The Multiple Linear Regression Analysis was performed to determine the predictive power of teacher leadership culture on teacher professionalism. The teacher leadership culture sub-dimensions were taken as an independent variable, and teacher professionalism was taken as a dependent variable. In the interpretation of the regression analyses, the standardized Beta $(\beta)$ coefficients and t-test results for their significance were examined. The significance of the data was decided according to the .05 level.

The Confirmatory Factor Analysis (CFA) was performed to determine whether the factor structures of the scales used in the study were compatible with the data of this study. The references regarding the confirmatory factor analysis compliance indices are as follows: The fact that the coefficient obtained from the GFI, AGFI was .85 (Anderson and Gerbing, 1984; Cole, 1987) or over .90 (Kline, 2005; Schumacker and Lomax, 1996) was considered a good compliance. The values of .10 and smaller obtained from the RMSEA are sufficient for compliance. The fact that the ratio of $\chi 2 / \mathrm{df}$ is between 2-5 indicates a good compliance, and the values smaller than 2 indicate perfect compliance (Jöreskog and Sörbom, 2001).

\section{Findings}

\subsection{Average, Standard Deviation and Correlations between the Variables}

The average and standard deviation values for the characteristics of teacher professionalism and teacher leadership culture and the results of correlation and regression analysis are presented in this chapter.

The correlations between the average and standard deviation values and research variables are presented in Table 1 . 
Table 1. Average and standard deviation values for the teacher leadership culture and teacher professionalism and the relationships between the teacher leadership culture and teacher professionalism

\begin{tabular}{lllllll}
\hline Variables & $\overline{\mathrm{X}}$ & $\mathbf{S}$ & $\mathrm{P}$ & $\mathrm{PC}$ & AS & SWE \\
\hline P & & & & & \\
PC & 4.14 & .65 & - & $.73^{* *}$ & $.66^{* *}$ & $.78^{* *}$ \\
AS & 3.99 & .78 & & $.73^{* *}$ & $.82^{* *}$ \\
SWE & 4.06 & .84 & & & $.86^{* *}$ \\
\hline
\end{tabular}

*** $<$ <.05 Note: Professionalism (P) Professional Cooperation (PC), Administrator's Support (AS), Supportive Working Environment (SWE

When Table 1 is examined, it is observed that the average values are above the medium level by $=4.14$ for teacher professionalism, $=3.99$ for professional cooperation, $=4.06$ for administrator's support and $=3.99$ for the supportive working environment. According to these findings, it is observed that the average values of the teacher leadership culture dimensions are close to each other. In Table 1, it was found out that there were significant positive relationships between professional cooperation and the characteristics of professionalism $(r=.73, \mathrm{p}<.01)$, between administrator's support and professionalism $(\mathrm{r}=.66, \mathrm{p}<.01)$ and between professionalism and supportive working environment $(\mathrm{r}$ $=.78, \mathrm{p}<.01)$.

\subsection{Prediction of Teacher Professionalism}

The results of the multiple linear regression analysis for the prediction of teacher professionalism by the teacher leadership culture are presented in Table 2.

Table 2. The results of the multivariate regression analysis between teacher professionalism and teacher leadership culture

\begin{tabular}{llllll}
\hline Variables & $\mathrm{B}$ & $\begin{array}{l}\text { Standar } \\
\mathrm{d} \text { Error }\end{array}$ & $\beta$ & $\mathrm{t}$ & $\mathrm{p}$ \\
\hline Fixed & 1.52 & .13 & & 11.45 & .00 \\
Professionalism & .23 & .05 & .28 & 4.14 & .00 \\
Administrator's support & -.06 & .05 & -.08 & -1.05 & .29 \\
Supportive working environment & .48 & .07 & .62 & 6.77 & .00 \\
\hline
\end{tabular}

$R=.80, R^{2}=.64, F=149.79, p<.05$

When Table 2 is examined, it is observed that professional cooperation, administrator's support, and supportive working environment all together explained $64 \%$ variance in teacher professionalism. When the independent variables were examined separately, the professional cooperation and supportive working environment of the teacher leadership culture sub-dimensions positively and significantly explained professionalism. It is observed that administrator's support has no significant explanatory power. Supportive working environment $(\beta=.62, \mathrm{p}<.05)$ and professional cooperation $(\beta=.28$, $\mathrm{p}<.05)$ appear respectively in terms of the explanatory power.

\subsection{Discussion, Conclusions and Recommendations}

In this study, the relationship between the schools' levels of having teacher leadership culture and teachers' professional behaviors was examined according to teacher perceptions. The results of the study reveal that the schools' levels of having teacher leadership culture and teacher professionalism levels are above the medium level. They also indicate that professional cooperation, school administrator's support and the level of having a supportive working environment at schools and teacher leadership give positive and significant relationships. In addition to this, the results of the study show that professional cooperation and supportive working environment at schools are important variables explaining teacher professionalism.

In the study, teachers' professionalism perceptions were found to be above the medium level. Although similar findings were produced in other studies (Kılınç, 2014; Koşar, 2015), research findings showing that teachers' professionalism perceptions are at lower levels were also achieved (Cerit, 2012). Teacher's professional behaviors emphasize professional commitment, cooperation, activities aimed at increasing the quality of teaching, and the fact that teachers take responsibility for ensuring student learning (Tschannen-Moran, Parish and DiPaola, 2006). In this context, these findings can be evaluated positively. Education becomes more qualified along with the professional behaviors of teachers (Hoque, Alam and Abdullah, 2011; McDonald, Son, Hindman and Morrison, 2005; Newmann, King and 
Youngs, 2000; Poekert, 2012; Şişman, 2011). In this respect, it can be stated that teachers make more contributions to school development, carry out studies for their professional development and participate in professional cooperation, depending on the fact that professional behaviors of teachers are at high level.

In the study, it is observed that the schools' levels of having teacher leadership culture were above the medium level and took values close to each other. These findings are similar to the findings of Demir (2014). On the other hand, this finding of the study can be regarded positively in terms of showing that there is a culture that supports teacher leadership at schools. In other words, schools are perceived as a peaceful environment among teachers in terms of professional cooperation, sharing knowledge and experience. Teacher leadership is supported at schools where teachers' unique behaviors are promoted (Wenner and Campbell, 2017), and there is a working environment based on respect, and ethical behaviors are exhibited (York-Barr and Duke, 2004). School administrator's support (Donaldson, 2006; DuFour and Eaker, 1998; Lambert, 2003), non-blocking working environments (K1lınç, 2014) and the creation of learning communities at schools (Fullan and Hargreaves, 1996) also play important roles in supporting teacher leadership. According to these statements, it can be stated that professional sharing, friend relationships, professional cooperation and solidarity at schools are at sufficient levels and that there is a culture that supports teacher leadership at schools. Nevertheless, it can be said that increasing this level to higher levels is important in terms of improving the quality of teaching performed at schools.

In the study, it is observed that there are significant positive relationships between professional cooperation, administrator's support and supportive working environment of teacher leadership culture dimensions and teacher professionalism. In the study, the highest relationship was found between supportive working environment and professionalism. The supportive working environment represents working environments in which there are mutual trust and communication, so teaching-oriented sharing increases to a higher level. So, teachers are expected to show high-level professional behaviors in a working environment based on peace and trust. In his study, Kılınç (2014) revealed that the supportive school culture that emphasizes intimate and confidential relationships between individuals enables teachers to show more professional behaviors. The communication and cooperation increase at schools along with an environment of trust and honesty (Tschannen-Moran, 2009; Dean, 2011), cooperation develops teacher's professional behaviors by encouraging more sharing and interpersonal learning (Webb et al., 2004). Therefore, it can be said that a supportive working environment is an important variable that strengthens teachers' professional behaviors.

In the study, a positive and significant relationship was found between the professional cooperation culture and teacher professionalism. Professional cooperation emphasizes studies for the realization of teachers' cooperation and common objectives. At schools where there is professional cooperation, learning communities are established for student learning (Danielson, 2006) and teaching practices aimed at bringing student learning to the highest level are carried out (Chamberland, 2009; Muijs and Harris, 2006). In a collaborative school culture, teachers can develop professional behaviors through in-class and out-of-class studies (Rizvi and Elliot, 2007). The fact that good practices are taken as examples and are implemented makes individuals more productive (Geist, 2002). It is also possible to expect schools to become a learning community by the realization of professional cooperation at schools. Thus, schools become places where different applications are learned and used (Mangrum, 2004). All kinds of cooperation that will improve student learning and professional development increase tendency to act professionally among teachers (Tschannen-Moran et al., 2006) and teachers take more responsibility for ensuring student development (Hord, 1997). Teachers show high standards in all areas at school along with collective practices and devote hard time and efforts for the improvement of schools (DuFour and Eaker, 1998; Hord, 1997; Morrisey, 2000; Öğdem, 2015). As it is understood from these statements, it can be said that teachers are expected to exhibit high professional behaviors with the strengthening of the professional cooperation.

In the study, it is observed that there is a positive and significant relationship between administrator's support and teacher professionalism. School administrator's support emphasizes the sharing of the leadership, encouraging participation at school and providing teachers with opportunities for leadership roles (Demir, 2014). Principal's support (Wenner and Campbell, 2017; York-Barr and Duke, 2004), distribution of leadership at school (Chamberland, 2009; Brosky, 2009), ensuring teachers' participation in school decisions (Chew and Andrews, 2010) and reliance on administrator (Koşar, 2015) allow teachers to take responsibility for higher levels of learning and to exhibit professional behaviors. Otherwise, teachers may not feel comfortable enough at schools due to administrators who overestimate the rules and procedures. Yirci (2017) states that an excessively rule-based school structure and administrator behaviors decrease professional behaviors. It can be said that teachers exhibit more professional behaviors along with the support of school administrators by the increase in their control feelings on their works. In other words, the fact that teachers feel that events are under their control can strengthen their efficacy beliefs (Bandura, 1997).

In the study, it is observed that teacher leadership culture dimensions significantly predict teachers' professional behaviors. It is observed that the supportive working environment and professional cooperation of teacher leadership 
culture dimensions are the significant positive predictors of professional behaviors. It is observed that the predictive power becomes intense in the supportive working environment and is followed by professional cooperation. The supportive working environment emphasizes a peaceful and trust-oriented environment at school that promotes cooperation and learning (Demir, 2014). In such a working environment, teachers' participation in administrative processes is ensured, colleagues are led in different areas (Hobson and Moss, 2010; Katzenmeyer and Moller, 2001), and the quality of teaching performed at school increases (Lambert, 2003). Supportive environments in which there are participation and trust may ensure that teachers show higher levels of professional behaviors. Strong relationships between individuals are influential in the development of social norms. These norms are also reflected in beliefs, attitudes, and behaviors of the whole group, respectively (Coleman, 1988). When a strong teacher cooperation and intimate relationships increase at schools, positive or negative thoughts and beliefs on teaching and uncovering the performance of students develop. In this case, it can be observed that teachers are more effective in different fields of activity of the school (Cybulski, Hoy and Sweetland, 2005). On the other hand, in this study, it is observed that professional cooperation is an important explanatory of professional behaviors. Professional cooperation emphasizes the collective behaviors of teachers and the creation of a collaborative environment (Demir, 2014). When teachers cooperate with other teachers and are supported, they perform more qualified studies (Harris and Muijs, 2005), encourage each other to do their jobs better (Danielson, 2006), and common objectives are formed (Gehrke, 1991). This can also be explained by the development of efficacy perceptions in teachers. The fact that teachers receive feedbacks from their colleagues improves efficacy belief in teachers (Bandura, 1997). So, teachers' efficacy beliefs develop by acting together and are expected to exhibit higher levels of professional behaviors. According to the results of the study, it is observed that administrator's support is not a significant predictor of professional behaviors although it is highly associated with professional behaviors. It can be stated that this result is not compatible with the expectations. Based on these statements, it can be said that the supportive working environment and professional cooperation that strengthen teacher leadership at schools are important variables in supporting professional behaviors.

Since the research results indicate that all dimensions of teacher leadership culture are associated with teacher professionalism, it is possible to focus on applications that will increase a supportive working environment, professional cooperation and administrator's support at schools. In this context, the facts that teachers work as a team for the supportive working environment at schools, teachers' successes are celebrated, and teachers are given responsibilities to strengthen trust at school can positively affect professional behaviors. It is possible to attach importance to the fact that teachers visit each other's lessons, work jointly on some projects and carry out projects by establishing teams for school development to ensure professional cooperation, in terms of developing professional behaviors. Furthermore, since administrator's support is associated with professional behaviors, it can be stated that the fact that school administrators create opportunities for teachers to act individually and organize activities that strengthen personal relationships with teachers will make positive contributions to professional behaviors. The research results have shown that the supportive working environment and professional cooperation are significant predictors of professionalism. In this context, it is suggestible to organize various social activities aimed at strengthening confidence, openness and communication environment at schools, to give teachers formal or informal leadership opportunities and to structure schools as learning communities in order to develop a supportive working environment and professional cooperation. On the other hand, the relationships of teacher leadership culture and professional behaviors with different variables can be investigated because, as a result of this study, teacher leadership culture at school was found to be an important variable in teacher performance. On the other hand, these studies can be supported by qualitative or mixed studies. Subsequent studies aimed at understanding the effects of these variables on school success and explaining cause-and-effect relationship have potential to contribute to the literature.

\section{References}

Adams, D., \& Gamage, D. T. (2008). A study of leadership effectiveness in a large VET institution in Australia. International Journal of Educational Management, 22, 214-228. https://doi.org/10.1108/09513540810861856

Agezo, C. K. (2009). School reforms in Ghana: A challenge to teacher quality and professionalism. IFE PsychologIA: An International Journal, 17(2), 40-64. https://doi.org/10.4314/ifep.v17i2.45302

Al-Hinai, A. M. (2007). The interplay between culture, teacher professionalism and teachers' Professional development at times of change. In T. Townsend \& R. Bates (eds.) In Handbook of teacher education globalization, standards and professionalism in times of change (pp. 41-52). The Netherlands: Springer. https://doi.org/10.1007/1-4020-4773-8_3

Anderson, J. C., \& Gerbing, D. (1984). The effect of sampling error on convergence, improper solutions, and goodness-of-fit indices for maximum likelihood confirmatory factor analysis. Psychometrika, 49, 155-173. https://doi.org/10.1007/BF02294170 
Bandura, A. (1997). Self-efficacy: The exercise of control. New York: W. H. Freeman and Company.

Barth, R. (2000). Building a community of learners. Principal, 79(4), 68-69.

Bayhan, G. (2011). Examination of teachers' professionalism (Unpublished doctoral thesis). Marmara Üniversitesi, İstanbul.

Bayram, N. (2013). Introduction to structural equation modeling: Amos applications. İstanbul: Güven Mücellit.

Beachum, F., \& Dentith, A. M. (2004). Teacher leaders creating cultures of school renewal and transformation. Educational Forum, 68, 276-286. https://doi.org/10.1080/00131720408984639

Beycioğlu, K. (2009). An evaluation of the leadership roles of teachers at elementary schools (The case of Hatay province) (Unpublished doctoral thesis). İnönü Üniversitesi, Malatya.

Borchers, B. T. (2009). A study to determine the practices of high school principals and central office administrators who effectively foster continuous professional learning in high schools (Doctoral dissertation). Retrieved from Dissertations and Theses database. (UMI No. 3389298)

Brosky, D. J. (2009). Micropolitics in the school: Teacher leaders' use of political skill and influence tactics (Doctoral dissertation). Oakland University.

Buckner, K. G., \& McDowelle, J. O. (2000). Opportunities, and support developing teacher leaders: Providing encouragement, NASSP Bulletin, 84, 35-41. https://doi.org/10.1177/019263650008461607

Bureau, S., \& Suquet, J. B. (2009). A professionalization framework to understand the structuring of work. European Management Journal, 27, 467-475. https://doi.org/10.1016/j.emj.2009.02.001

Can, N. (2006). The roles and strategies of the principal in the development of teacher leadership. Erciyes Üniversitesi Sosyal Bilimler Enstitüsü Dergisi, 21(2), 349-363.

Cansoy, R., \& Parlar, H. (2017). Teacher professionalism as a predictor of school development. Ahi Evran Üniversitesi Kırşehir Eğitim Fakültesi Dergisi, 18(1), 269-289.

Carr, D. (2000). Professionalism and ethics in teaching. NY: Taylor\& Francis Group.

Celep, C. (2002). Learning culture at primary schools. Kuram ve Uygulamada Eğitim Yönetimi, 8(3), 356-373.

Cerit, Y. (2012). The relationship between the bureaucratic structure of the school and the professional behaviors of classroom teachers. Kuram ve Uygulamada Eğitim Yönetimi 18(4), 497-521.

Chamberland, L. (2009). Distributed leadership: Developing a new practice: An action research study (Doctoral dissertation). University of California.

Chew, J. O. A., \& Andrews, D. (2010). Enabling teachers to become pedagogical leaders: Case studies of two IDEAS schools in Singapore and Australia. Educational Research for Policy and Practice, 9(1), 59-74. https://doi.org/10.1007/s10671-010-9079-0

Cole, D. A. (1987). Utility of confirmatory factor analysis in test validation research. Journal of Consulting and Clinical Psychology, 55, 1019-1031. https://doi.org/10.1037/0022-006X.55.4.584

Coleman, J. S. (1988). Social Capital in the Creation of Human Capital. American Journal of Sociology, 94, pp.95120. https://doi.org/10.1086/228943

Coleman, M. R., Gallagher, J. J., \& Job, J. (2012). Developing and sustaining professionalism within gifted education. Gifted Child Today, 35(1), 27-36. https://doi.org/10.1177/1076217511427511

Crowther, F., Ferguson, M., \& Hann, L. (2009). Developing teacher leaders: How teacher leadership enhances school success. CA: Corwin Press.

Cybulski, T. G., Hoy, W. K., \& Sweetland, S. R. (2005). The roles of collective efficacy of teachers and fiscal efficiency in student achievement. Journal of Educational Administration, 43(5), 439-461. https://doi.org/10.1108/09578230510615224

Danielson, C. (2006). Teacher leadership that strengthens professional practice. VA: ASCD

Dean, S. D. (2011). Collegial leadership, teacher professionalssm, faculty trust: Predicting teacher academic optimism in elementary schools (Doctoral dissertation), The University of Alabama.

Demir, K. (2014). Teacher leadership culture scale: validity and reliability study. İlköğretim Online, 13(2), 334-344.

Demir, K. (2015). The effect of organizational trust on the culture of teacher leadership in primary schools. Educational Sciences: Theory \& Practice, 15(3), 621-634. https://doi.org/10.12738/estp.2015.3.2337 
Demirkasımoğlu, N. (2010). Defining "Teacher professionalism" from different perspectives. Procedia Social and Behavioral Sciences, 9, 2047-2051. https://doi.org/10.1016/j.sbspro.2010.12.444

Demirtaş, Z. (2010). The relationship between school culture and student success. Eğitim ve Bilim Dergisi, 35(158), 3-13.

DuFour, R., \& Eaker, R. (1998). Professional learning communities at work: Best practices for enhancing student achievement. Bloomington, IN: Solution Tree Press.

Evans, L. (2011). The 'shape' of teacher professionalism in England: Professional standards, performance management, professional development and the changes proposed in the 2010 white paper. British Educational Research Journal, 37(5), 851-870. https://doi.org/10.1080/01411926.2011.607231

Fullan, M., \& Hargreaves, A. (1996). What's worth fighting for in your schools? New York, NY: Teachers College Press.

Gaffney, M., \& Faragher, R. (2010). Sustaining improvement in numeracy: Developing pedagogical content knowledge and leadership capabilities in tandem. Mathematics Teacher Education and Development, 12(2), 72-83.

Gehrke, N. (1991). Developing Teachers' Leadership Skills. ERIC Digest. Retrieved from http://files.eric.ed.gov/fulltext/ED330691.pdf On April, 21, 2016.

Geist, J. R. (2002). Predictors of faculty trust in elementary schools: Enabling bureaucracy, teacher professionalism, and academic press, (Doctoral Dissertation). The Ohio State University.

Gil'meeva, R. K. (1999). The teacher's professionalism in the sociological dimension. Russian Education \& Society, 41(10), 48-63. https://doi.org/10.2753/RES1060-9393411048

Goepel, J. (2012). Upholding public trust: An examination of teacher professionalism and the use of teachers' standards in England. Teacher Development, 16(4), 489-505. https://doi.org/10.1080/13664530.2012.729784

Gordin, L. (2010). Conceptualization and support of the role of teachers serving as team leaders in a professional learning community (Doctoral dissertation). Azusa Pacific University

Gravetter, F., \& Wallnau, L. (2014). Essentials of statistics for the behavioral sciences (8th ed.). Belmont, CA: Wadsworth.

Guskey, R. (1986). Staff development and the process of teacher change. Educational Researcher, 15(5), 5-12. https://doi.org/10.3102/0013189X015005005

Hargreaves, A. (2000). Four ages of professionalism and professional learning. Teachers and Teaching, 6(2), 151-182. https://doi.org/10.1080/713698714

Harris, A., \& Muijs, D. (2005). Improving schools through teacher leadership. Maidenhead, London: Open University Press.

Harrison, R. (1972). Understanding your organization's character. Harvard Business Review, 50(3), 119-128.

Heller, M. F., \& Firestone, W. A. (1995). Who's in charge here? sources of leadership for change in eight schools. The Elementary School Journal, 96(1), 65-86. https://doi.org/10.1086/461815

Hess, F. M., \& Fennell, M. (2015). Point-counterpoint: Teacher professionalism. Kappa Delta Pi Record, 51(4), 159. https://doi.org/10.1080/00228958.2015.1089618

Hildebrandt, S. A., \& Eom, M. (2011). Teacher professionalization: Motivational factors and the influence of age. Teaching and Teacher Education, 27(2), 416-423. https://doi.org/10.1016/j.tate.2010.09.011

Hobson, L. D., \& Moss, L. (2010). Analysis of teacher leadership as a teacher development model: an opportunity for reform and improved practice. National Forum of Educational Administration and Supervision Journal, 27(2), $28-42$.

Hopkins, D. (2007). Every school a great school: Realizing the potential of system leadership. New York, NY: Open University Press.

Hoque, K. E., Alam, G. M., \& Abdullah, A. G. K. (2011). Impact of teachers' professional development on school improvement-an analysis at Bangladesh standpoint. Asia Pacific Education Review, 12(3), 337-348. https://doi.org/10.1007/s12564-010-9107-z

Hord, S. (1997). Professional learning communities: Communities of continuous inquiry and improvement. Retrieved from http://files.eric.ed.gov/fulltext/ED410659.pdf On May, 9, 2017. 
Hoy, W. K., \& Sweetland, S. R. (2001). Designing better schools: The meaning and measure of enabling school structures. Educational Administration Quarterly, 37(3), 296-321. https://doi.org/10.1177/00131610121969334

Hoy, W. K., Tarter, C. J., \& Bliss, J. R. (1990). Organizational climate, school health, and effectiveness: a comparative analysis. Educational Administration Quarterly, 26(3), 260-279. https://doi.org/10.1177/0013161X90026003004

Hunzicker, J. (2012). Professional development and job-embedded collaboration: How teachers learn to exercise leadership. Professional Development in Education, 38, 267-289. https://doi.org/10.1080/19415257.2012.657870

Jöreskog, K., \& Sörbom, D. (2001). LISREL 8.51. Mooresvile: Scientific Software.

Karaca, D. (2015). The effect of the level of bureaucratization in primary and secondary schools on teacher professionalism (Unpublished doctoral thesis). Pamukkale Üniversitesi, Denizli.

Katzenmeyer, M., \& Moller, G. (2001). Awakening the sleeping giant: Helping teachers develop as leaders. Thousand Oaks, CA: Corwin Press.

K1lınç, A. Ç. (2014). School culture as a predictor of teacher professionalism. Eğitim ve Bilim, 39(174), 105-118.

Kincheloe, J. L. (2004). The knowledge of teacher education: Developing a critical complex epistemology. Teacher Education Quarterly, 31(1), 49-66.

Kline, R. B. (2005). Principle and practice of structural equation modeling. New York, NY: Guilford.

Koşar, S. (2015). Reliance on school principal and self-efficacy as the predictors of teacher professionalism. Eğitim ve Bilim, 40(181), 255-270.

Lambert, L. (2003). Leadership capacity for lasting school improvement. Alexandria, VA: Association for Supervision and Curriculum Development. https://doi.org/10.1080/1363243032000150953

Lumpkin, A., Claxton, H., \& Wilson, A. (2014). Key characteristics of teacher leaders in schools. Administrative Issues Journal: Education, Practice, and Research, 4(2), 59-67. https://doi.org/10.5929/2014.4.2.8

Marzano, R. J., Waters, T., \& McNulty, B. A. (2005). School leadership that works from research to results. Alexandria, VA: ASCD.

McCay, L. Flora, J., Hamilton, A., \& Riley, J. F. (2001). Reforming schools through teacher leadership: A program for classroom teachers as agents of change. Educational Horizons, 79(3), 135-142.

McDonald Connor, C., Son, S., Hindman, A. H., \& Morrison, F. J. (2005). Teacher qualifications, classroom practices, family characteristics, and preschool experience: Complex effects on first graders' vocabulary and early reading outcomes. Journal of School Psychology, 43(4), 343-375. https://doi.org/10.1016/j.jsp.2005.06.001

Morrissey, M. S. (2000). Professional learning communities: An ongoing exploration. Austin, TX: Southwest Educational Development Laboratory. Retrieved from http://www.willettsurvey.org/TMSTN/PLCs/plc-ongoing.pdf On May, 8, 2017.

Muijs, D., \& Harris, A. (2006). Teacher led school improvement: Teacher leadership in the UK. Teaching and Teacher Education, 22, 961-972. https://doi.org/10.1016/j.tate.2006.04.010

Mullins, L. J. (2016). Management and organizational behavior (10th ed.). London: Pitman.

Newmann, F. M., King, M. B., \& Youngs, P. (2000). Professional development that addresses school capacity: Lessons from urban elementary schools. American Journal of Education, 108(4), 259-299. https://doi.org/10.1086/444249

OECD [Organisation for Economic Co-operation and Development] (2016). Supporting Teacher Professionalism: Insights from TALIS 2013, OECD Publishing, Paris. http://dx.doi.org/10.1787/9789264248601-en

Öğdem, Z. (2015). Team leadership and organizational climate in elementary schools as a professional learning community (Unpublished doctoral thesis). Gazi Üniversitesi, Ankara.

Özdemir, S. (2012). The relationship between school culture and organizational health in primary schools. Kuram ve Uygulamada Eğitim Yönetimi, 18(4), 599-620.

Poekert, P. E. (2012). Teacher leadership and professional development: Examining links between two concepts central to school improvement. Professional Development in Education, 38(2), 169-188.

https://doi.org/10.1080/19415257.2012.657824 
Raymond, S. M. (2006). Professionalism and identity in teacher education: Implications for teacher reform (Doctoral dissertation). Northern Arizona University.

Rizvi, M., \& Elliott, B. (2007). Enhancing and sustaining teacher professionalism in Pakistan. Teachers and Teaching, 13(1), 5-19. https://doi.org/10.1080/13540600601106021

Robbins, S. (1990). Organization theory (3rd ed.). New Jersey: Prentice Hall.

Rolff, H. G. (2008). Konzepte und Verfahren der Schulentwicklung. Studienbrief im Rahmen des Fernstudiengangs Schulmanagement, TU Kaiserslautern.

Schein, E. H. (2010). Organizational culture and leadership (4th ed.). San Fransisco: Jossey-Bass.

Schumacker, R. E., \& Lomax, R. G. (1996). A beginner's guide to structural equation modeling. Hilsdale, NJ: Erlbaum. https://doi.org/10.1080/10705519609540025

Shantz, D., \& Prieur, P. D. (1996). Teacher professionalism and school leadership: An antithesis? Education, 116(3), 393-396.

Silva, D. Y., Gimbert, B., \& Nolan, J. (2000). Sliding the doors: Locking and unlocking possibilities for teacher leadership. Teachers College Record, 102(4), 779-804. https://doi.org/10.1111/0161-4681.00077

Şişman, M. (2002). Organizations and cultures. Ankara: PegemA.

Şişman, M. (2011). Seeking excellence in education. Ankara: Pegem Akademi

Smylie, M. A., \& Brownlee-Conyers, J. (1992). Teacher leaders and their principals: Exploring the development of new working relationships. Educational Administration Quarterly, 28(2), 150-184. https://doi.org/10.1177/0013161X92028002002

Smylie, M. A., \& Denny, J. W. (1990). Teacher leadership: Tensions and ambiguities in organizational perspective. Educational Administration Quarterly, 26(3), 235-259. https://doi.org/10.1177/0013161X90026003003

Tschannen-Moran, M. (2009). Fostering teacher professionalism in schools: The role of leadership orientation and trust. Educational Administration Quarterly, 45(2), 217-247. https://doi.org/10.1177/0013161X08330501

Tschannen-Moran, M., Parish, J. ve DiPaola, M. F. (2006). School climate and state standards: How interpersonal relationships influence student achievement. Journal of School Leadership, 16, 386-415.

Wagner, C. R. (2006). The school leader's tool for assessing and improving school culture. Principal Leadership, 7(4), 41-44.

Webb, R., Vulliamy, G., Hämäläinen, S., Sarja, A., Kimonen, E., \& Nevalainen, R. (2004). A comparative analysis of primary teacher professionalism in England and Finland. Comparative Education, 40(1), 83-107. https://doi.org/10.1080/0305006042000184890

Wenner, J. A., \& Campbell, T. (2017). The theoretical and empirical basis of teacher leadership: A review of the literature. Review of Educational Research, 87(1), 134-171. https://doi.org/10.3102/0034654316653478

Yirci, R. (2017). Obstacles to teacher professionalism and solution proposals. Ahi Evran Üniversitesi Kırşehir Eğitim Fakültesi Dergisi, 18(1), 503-522.

York-Barr, J., \& Duke, K. (2004). What do we know about teacher leadership? findings from two decades of scholarship. Review of Educational Research, 74(3), 255-316. https://doi.org/10.3102/00346543074003255

\section{Copyrights}

Copyright for this article is retained by the author(s), with first publication rights granted to the journal.

This is an open-access article distributed under the terms and conditions of the Creative Commons Attribution license which permits unrestricted use, distribution, and reproduction in any medium, provided the original work is properly cited. 